\title{
KEPUASAN PELANGGAN MENGINAP PADA HOTEL BERBINTANG DI DAERAH ISTIMEWA YOGYAKARTA (Survey Pelanggan Pada Hotel Bintang Tiga, Empat dan Lima Di Daerah Istimewa Yogyakarta)
}

\author{
MASKURI SUTOMO \\ (Dosen Jurusan Manajemen FE Univ. Tadulako Palu Sulawesi Tengah)
}

\begin{abstract}
Abstrak
Yogyakarta merupakan lahan yang strategis bagi perkembangan sektor industri jasa, khususnya hotel sebagai sarana akomodasi bagi turis. Pertumbuhan wisatawan baik mancanegara maupun domestik yang datang menggunakan jasa akomodasi hotel berbintang semakin meningkat di Daerah Istimewa Yogyakarta, semakin banyak wisatawan yang nginap di Daerah Istimewa Yogyakarta, akan semakin tinggi pendapatan yang akan diperoleh, karena hampir sepertiga dari uang saku mereka akan dialokasikan kepada urusan akomodasi. Situasi persaingan yang ketat dalam industri perhotelan di Daerah Istimewa Yogyakarta telah menyebabkan perusahaan-perusahaan sulit untuk meningkatkan jumlah pelanggan. Hasil pra survei mengindikasikan bahwa pelanggan hotel bintang dua dan lima lebih merasakan manfaat sosial, fungsional dan emosional dibandingkan pengorbanannya dalam mengkonsumsi layanan hotel berbintang di Daerah Istimewa Yogyakarta. Peningkatan kualitas layanan yang diberikan kepada pelanggan dimungkinkan dapat mengurangi kegagalan pelayanan dan memberikan kepuasan. Bila hal tersebut dapat diwujudkan maka pelanggan senantiasa akan mengkonsumsi dan berperilaku positif terhadap jasa tersebut.

Penelitian ini menggunakan pendekatan ilmu manajemen pemasaran. Metode penelitian yang digunakan adalah metode penelitian survei, yaitu penelitian yang menggunakan kuesioner sebagai alat pengumpulan data yang pokok. Unit analisis dalam penelitian ini adalah pelanggan atau tamu hotel yang menginap pada hotel berbintang di Daerah Istimewa Yogyakarta. Unit obeservasi dalam penelitian adalah pelanggan yang menginap pada hotel bintang tiga, empat dan di Daerah Istimewa Yogyakarta. Hotel bintang tiga, empat dan lima di Daerah Istimewa Yogyakarta berjumlah 17 buah.

Hotel bintang tiga empat dan lima di Daerah Istimewa Yoyakarta belum memberikan kepuasan pelanggan yang maksimal. Hal ini ditunjukkan lebih tingginya harapan pelanggan terhadap kontak personal, fasilitas fisik pendukung dan peralatan dibandingkan kinerja yang dirasakan oleh pelanggan.
\end{abstract}

\section{Kata Kunci : Kepuasan Pelanggan}

\section{LATAR BELAKANG PENELITAN}

Daerah Istimewa Yogyakarta merupakan salah satu daerah yang menjadi tujuan wisata utama di Indonesia. Sebagai daerah wisata, Yogyakarta merupakan lahan yang yang strategis bagi perkembangan sektor industri jasa, khususnya hotel sebagai sarana akomodasi bagi turis. Peluang berinvestasi pada subsektor ini ditunjang oleh beberapa hal yaitu : kondisi lingkungan yang aman dan damai di wilayah yang etnisnya homogen, lokasi strategis di jantung Pulau Jawa, infrastruktur yang meliputi sebuah bandara internasional, bangunan-bangunan dan fasilitas publik yang moderen, rangkaian atraksi wisata dan aktivitas kebudayaan yang luas dan yang diilhami oleh salah satu peradaban tertua dan paling menarik, serta jadwal penerbangan yang cukup padat ke ibu kota Jakarta dan Bali yang masingmasing ditempuh dalam waktu kurang dari satu jam.

Pertumbuhan wisatawan baik mancanegara maupun domestik yang datang menggunakan jasa akomodasi hotel berbintang semakin meningkat di Daerah Istimewa Yogyakarta, Pertumbuhan jumlah wisata yang menginap pada hotel di DIY sebesar $14,84 \%$ pada tahun 2004, merupakan peluang yang cukup baik bagi pengembangan pasar dalam industri ini. Industri perhotelan di Daerah Istimewa Yogyakarta juga memberikan kontribusi yang cukup besar bagi PDRB. Berdasarkan data BPS DIY Sub sektor hotel pada tahun 2003 memberikan 
kotribusi kepada PDRB DIY sebesar Rp.324.552.000.000 dan meningkat pada tahun 2004 sebesar Rp.346.529.000.000 pada harga berlaku. Industri perhotelan merupakan lokomotif pembangunan, setelah dicanangkan dalam tematik program tahunan Daerah Istimewa Yogyakarta tahun 2003. Ini terbukti bahwa PAD Yogyakarta 24 $\%$ dari Pajak Hotel, merupakan perolehan terbesar kedua setelah pajak bumi dan bangunan. Hal itu menandakan bahwa semakin banyak wisatawan yang nginap di Daerah Istimewa Yogyakarta, akan semakin tinggi pendapatan yang akan diperoleh, karena hampir sepertiga dari uang saku mereka akan dialokasikan kepada urusan akomodasi. Berdasarkan BPS masing-masing Daerah Tujuan Wisata (DTW) 2004, Daerah Istimewa Yogyakarta juga merupakan daerah dimana industri perhotelan memberikan kontibusi terbesar kedua setelah Bali kepada PAD, dibandingkan 10 DTW di Indonesia.

Situasi persaingan yang ketat dalam industri perhotelan di Daerah Istimewa Yogyakarta telah menyebabkan perusahaan-perusahaan sulit untuk meningkatkan jumlah pelanggan. Di pasar yang sudah ada, terlalu banyak produk jasa hotel dengan berbagai keunggulan serta nilai lebih yang ditawarkan oleh para pesaing, sehingga sulit bagi perusahaan untuk merebut pangsa pasar pesaing.

Berdasarkan tabel di atas terlihat bahwa ratarata tingkat pengunian kamar hotel berbintang di Daerah Istimewa Yogyakarta sejak tahun 1995 masih belum mencapai $50 \%$ dan pada tahun 2004 pertumbuhan tingkat hunian menurun sebesar $1,74 \%$. Hal ini menunjukkan bahwa rata-rata hotel berbintang belum dapat mencapai target tingkat hunian ideal yang diharapkan "Kondisi semacam ini membuat banyak hotel yang tidak kuat. Mereka hanya beroperasi seadanya, atau dengan kata lain hidup segan tetapi mati pun tidak mau," ( Ketua Umum Persatuan Hotel dan Restoran Indonesia Provinsi DIY, S. D Sudarto).

Rendahnya rata-rata lama menginap wisatawan pada hotel bintang di Yogyakarta menunjukkan ketidakinginan wisatawan untuk menginap kembali di hotel tersebut. Pelanggan atau tamu hotel menginginkan pengalaman baru terhadap layanan yang diterima dari sebuah hotel, proses pencarian ini akan berhenti manakala pelanggan memperoleh nilai dan kepuasan dari sebuah produk atau jasa.

Pengusaha hotel lebih menginginkan perputaran tamu yang lebih rendah namun waktu menginap yang relatif panjang. Hal ini berkaitan dengan unit cost tamu yang menginap lama lebih kecil dibandingkan dengan tamu yang menginap singkat. Unsur biaya ini meliputi welcome drink, stationery dan biaya administrasi lainnya. Apabila hal ini berlanjut secara terus menerus tanpa dilakukan perbaikan dan pembenahan dari pengusaha hotel agar tamu dapat menginap lebih lama, maka kemungkinan akan berdampak pada nilai yang dirasakan oleh pelanggan dan pendapatan perusahaan atau keberadaan sebuah hotel di dalam industri.

Hasil pra survei mengindikasikan bahwa pelanggan hotel bintang dua dan lima lebih merasakan manfaat sosial, fungsional dan emosional dibandingkan pengorbanannya dalam mengkonsumsi layanan hotel berbintang di Daerah Istimewa Yogyakarta. Berdasarkan hasil wawancara dengan ketua PHRI Cabang Yogyakarta, rata-rata hotel berbintang di Daerah Istimewa Yogyakarta terjadi peningkatan jumlah keluhan pelanggan khususnya terjadi pada hotel bintang 3 dan 4 yang di alamatkan pada bagian manajemen masing-masing hotel bintang di DIY sejak tahun 2004 hingga 2005. Keluhan pelanggan merupakan ungkapan rasa ketidakpuasan dan kegagalan pelayanan. Pelanggan yang mengalami kegagalan pelayanan yang diterimanya, cenderung akan memberikan informasi yang negatif kepada orang lain terhadap jasa tersebut (Matilda; 2003). Informasi negatif mengenai suatu perusahaan akan berdampak pada citra perusahaan tersebut dimata pelanggan.

Peningkatan kualitas layanan yang diberikan kepada pelanggan dimungkinkan dapat mengurangi kegagalan pelayanan dan memberikan kepuasan (Matilda;2003). Bila hal tersebut dapat diwujudkan maka pelanggan senantiasa akan mengkonsumsi dan berperilaku positif terhadap jasa tersebut, sikap demikian mengidikasikan loyalitas pelanggan.

Rumusan dari kepuasan pelanggan menurut Tse dan Wilton dalam Tjiptono (1997:36), dapat diperoleh sebagai berikut: kepuasan pelanggan $=f$ (expectations, perceived performance). Dari persamaan tersebut dapat diketahui bahwa ada dua variabel utama yang menentukan kepuasan pelanggan, yaitu expectations dan perceived performance. Apabila perceived performance melebihi expectations, maka pelanggan akan puas, tetapi bila sebaliknya maka pelanggan akan merasa tidak puas. Jika pelanggan tidak puas, 
maka perusahaan akan kehilangan kesempatan untuk membangun loyalitas. Kepuasan atau ketidakpuasan yang dihasilkan sangat besar pengaruhnya dalam membangun loyalitas pelanggan.

Dalam penelitian ini pelanggan yang mengkonsumsi produk inti dari hotel disebut pelanggan yang menginap di hotel, dimana selanjutnya dalam penulisan disebut sebagai pelanggan. Berdasarkan uraian fenomena yang telah diungkap di atas, penulis tertarik untuk melakukan penelitian mengenai "Kepuasan pelanggan yang menginap pada Hotel Berbintang di Daerah Istimewa Yogyakarta"

\section{PERMASALAHAN}

Berdasarkan latar belakang pendahuluan yang telah dikemukakan maka diidentifikasikan masalah sebagai berikut :

1. Bagaimana kepuasan pelanggan pada kontak personal pada hotel bintang di Daerah Istimewa Yogyakarta.

2. Bagaimana kepuasan pelanggan pada fasilitas fisik pendukung pada hotel bintang di Daerah Istimewa Yogyakarta.

Bagaimana kepuasan pelanggan pada peralatan pada hotel bintang di Daerah Istimewa Yogyakarta.

\section{METODE PENELITIAN}

Penelitian ini menggunakan pendekatan ilmu manajemen pemasaran. Metode penelitian yang digunakan adalah metode penelitian survei, yaitu penelitian yang menggunakan kuesioner sebagai alat pengumpulan data yang pokok. Jenis penelitian ini adalah deskriptif dan verifikatif, dimana tujuan penelitian deskriptif untuk memperoleh gambaran tentang kepuasan pelanggan. Sedangkan penelitian veripikatif bertujuan untuk menguji hipotesis melalui pengumpulan data di lapangan.

Unit analisis dalam penelitian ini adalah pelanggan atau tamu hotel yang menginap pada hotel berbintang di Daerah Istimewa Yogyakarta Adapun lokasi hotel di Daerah Istimewa Yogyakarta terdapat di Kotamadya Yogyakarta, Kabupaten Sleman, dan Gunung Kidul.

\section{POPULASI PENELITIAN}

Unit obeservasi dalam penelitian adalah pelanggan yang menginap pada hotel bintang tiga, empat dan di Daerah Istimewa Yogyakarta. Hotel bintang tiga, empat dan lima di Daerah Istimewa Yogyakarta berjumlah 17 buah. Penetapan hotel kelas bintang tiga, empat dan lima yang diangkat dalam unit analisis penelitian ini bedasarkan kriteria, Berdasarkan kriteria di atas maka dari 17 hotel yang termasuk hotel bintang tiga, empat dan lima, hanya 12 hotel. Populasi dalam penelitian ini adalah seluruh pelanggan yang menginap pada hotel berbintang di Daerah Istimewa Yogyakarta, dengan ciri-ciri yang disesuaikan dengan tujuan penelitian

\section{HASIL PEMBAHASAN}

Kepuasan Pelanggan diukur dengan tiga sub variabel yaitu kontak person, fasilitas fisik pendukung, dan peralatan. Dengan jumlah indikator (item pertanyaan) yang digunakan sebanyak 10 item. Hasil tanggapan responden terhadap kepuasan pelanggan untuk setiap item pertanyaan dalam setiap sub variabel dapat di deskripsikan pada analisis berikut:

\subsection{Kepuasan Pelanggan Pada Kontak Personal Pada Hotel Bintang di Daerah Istimewa Yogyakarta}

Kontak personal adalah hubungan atau kontak yang terjadi dalam proses penyampaian jasa hotel berlangsung antara karyawan atau penyedia jasa dengan konsumen. Pernyataan responden terhadap kontak personal antara karyawan dengan konsumen diukur dengan 3 indikator yang tercermin dalam item-item pertanyaan yang tersaji sebagai berikut :

\section{Keramahan Karyawan Pada Hotel Bintang di Daerah Istimewa Yogyakarta.}

Tanggapan responden yang menginap pada hotel bintang di Daerah Istimewa Yogyakarta mengenai kepuasan terhadap keramahan 
karyawan dalam melayani tamu hotel, yang dihasilkan dari perbandingan antara harapan dengan kinerja.

Data pada tabel 5.1 menunjukkan bahwa pelanggan belum merasa puas terhadap keramahan karyawan hotel kepada pelanggan. Hotel bintang tiga, memberikan tingkat kepuasan yang lebih tinggi dibandingkan dengan bintang empat dan lima di Daerah Istimewa Yogyakarta. Tingkat kepuasan yang rendah pada hotel bintang lima dimungkinkan karena tingginya harapan yang nyatakan oleh responden. Harapan pelanggan terhadap keramahan dipengaruhi oleh pengalaman pada masa lalu, iklan, informasi dari mulut kemulut maupun kebutuhan pelanggan tersebut, sehingga perbedaan pengalaman dan kebutuhan akan keramahan pada masing-masing sekmen kelas hotel akan mempengaruhi besarnya harapan responden tersebut.

Karamahan karyawan merupakan bagian penting dalam mengukur kualitas penyampaian jasa kepada pelanggan, dengan sikap ramah karyawan maka pelanggan akan merasa nyaman dan senang terhadap jasa yang ditawarkan. Hal ini perlu menjadi perhatian bahwa dalam bisnis jasa yang selalu terjadi personal kontak antara konsumen dan penyedia jasa, sifat keramahan, sopan satun merupakan variabel yang dapat mempengaruhi kepusan konsumen.

\section{Ketulusan Karyawan Dalam Melayani Tamu Hotel Pada Hotel Bintang di Daerah Istimewa Yogyakarta.}

Tanggapan responden yang menginap pada hotel bintang di Daerah Istimewa Yogyakarta mengenai kepuasan terhadap ketulusan karyawan dalam melayani tamu hotel, yang dihasilkan dari perbandingan antara harapan dengan kinerja, dapat dilihat pada Tabel 5.1. Data tersebut mengindikasikan bahwa, hotel bintang tiga, empat dan lima di Daerah Istimewa Yogakarta hampi mememenuhi harapan akan ketulusan karyawan dalam memberikan layanan kepada pelanggan. Hal ini ditunjukkan dari lebih besarnya nilai harapan responden hotel bintang tiga, empat dan lima. Hotel bintang tiga memberikan tingkat kepuasan yang lebih tinggi dibandingkan dengan bintang tiga dan empat, walaupun harapan respondennya tinggi namun didukung oleh kinerja karyawan yang tinggi.
Dalam bisnis perhotelan ketulusan karyawan dalam melayani pelanggan merupakan sikap dari seorang karyawan yang diharapkan oleh pelanggan. Sikap tulus yang diperlihatkan karyawan seperti kesediaan menolong pada saat menyambut tamu, ketidak nampakan kesan sibuk dari karyawaan pada saat melayani tamu, kemauan karyawan membawakan tas tamu dan mengantar tamu ke kamarnya dengan tulus merupakan hal penting untuk diperhatikan dalam pemasaran jasa hotel. Dengan ketulusan yang diperlihatkan oleh karyawan hotel, maka pelangga akan merasa dan dianggap penting oleh pemberi layanan.

\section{Kecepatan Karyawan Melayani Permintaan Tamu Pada Hotel Bintang di Daerah Istimewa Yogyakarta.}

Tanggapan responden yang menginap pada hotel bintang di Daerah Istimewa Yogyakarta mengenai kepuasan terhadap kecepatan karyawan dalam melayani permintaan tamu hotel, yang dihasilkan dari perbandingan antara harapan dengan kinerja, dapat dilihat pada Tabel 5.1.

Hasil penelitian mengindikasikan bahwa, hotel bintang tiga, empat dan lima di Daerah Istimewa Yogakarta belum dapat mememenuhi harapan akan kecepatan karyawan dalam melayani pemintaan pelanggan. Hal ini ditunjukkan dari lebih besarnya nilai harapan responden akan kecepatan karyawan dalam melayani permintaan pelanggan pada hotel bintang tiga, empat dan lima dibandingkan dengan nilai, sehingga diperoleh total indek kepuasan untuk kecepatan karyawan dalam melayani permintaan pelanggan pada hotel bintang sebesar $85 \%$. Hasil tersebut memperlihatkan hotel bintang empat lebih mampu memberikan tingkat kepuasan dibandingkan dengan bintang tiga dan lima. Harapan responden bintang lima pada kecepatan karyawan lebih tinggi dari kedua kelas hotel, hal ini dimungkinkan karena faktor kebutuhan pelanggan yang dipengaruhi oleh persepsi akan kualitas yang seharusnya diberikan hotel berkelas bintang lima.

Dalam kontak personal yang dilakukan antara karyawan dan pelanggan, salah satu ukuran kualitas layanannya adalah faktor kecepatan karyawan dalam melayani pelangga. Perbedaan antara harapan pelanggan pada kecepatan layanan karyawan dengan kinerja karyawan yang 
dirasakan merupakan faktor yang menyebabkan ketidak puasan konsumen. Selain itu perbedaan persepsi kecepatan layanan antara pelanggan dan karyawan maupun manajemen dapat mencipatakan gab ketidak puasan bagi konsumen. Sebagai contoh, manajemen menetapkan suatu sistem bahwa untuk check out termasuk penyelesaian tagihan-tagihan dan administrasi lainnya akan dilayani dalam waktu tidak lebih dari 15 menit. Tetapi kenyataannya konsumen sudah mulai resah dan mengomel setelah 10 menit. Ini berarti sistem yang ditetapkan oleh manajemen menyebabkan terjadinya ketidakpuasan tamu. Mungkin saja manajemen berpikir bahwa waktu 15 menit itu merupakan waktu yang singkat tetapi tidak demikian dengan tamu.

4. Total Kepuasan Pelanggan Terhadap Kontak Person Pada Hotel Bintang di Daerah Istimewa Yogyakarta.

Untuk mengetahui total skor tanggapan responden terhadap kepuasan responden pada kontak personel yang terjadi pada hotel bintang di Daerah Istimewa Yogyakarta dapat di lihat pada Tabel 5.1 berikut :

Tabel 5.1. Total Kepuasan Pelanggan Terhadap Kontak Person

\begin{tabular}{|l|l|c|c|c|c|c|c|c|}
\hline \multirow{2}{*}{ Ukuran } & \multicolumn{6}{|c|}{ Distribusi Tanggapan Responden Pada Contact Personel } \\
\cline { 2 - 9 } & No. & 5 & 4 & 3 & 2 & 1 & $\begin{array}{l}\text { Total } \\
\text { Skor }\end{array}$ & $\begin{array}{l}\text { Tingkat } \\
\text { Kepuasan }\end{array}$ \\
\hline Keramahan & Harapan & 231 & 69 & 0 & 0 & 0 & 1431 & 88,54 \\
Karyawan & Kinerja & 88 & 191 & 21 & 0 & 0 & 1267 & \\
\hline Ketulusan & Harapan & 167 & 133 & 0 & 0 & 0 & 1367 & 91,51 \\
Karyawan & Kinerja & 79 & 193 & 28 & 0 & 0 & 1251 & \\
\hline Kecepatan & Harapan & 205 & 95 & 0 & 0 & 0 & 1405 & 87,18 \\
Karyawan & Kinerja & 83 & 159 & 58 & 0 & 0 & 1225 & \\
\hline Total & Harapan & 603 & 297 & 0 & 0 & 0 & 4203 & 89,05 \\
& Kinerja & 250 & 543 & 107 & 0 & 0 & 3743 & \\
\hline
\end{tabular}

Sumber : Hasil Pengolahan Kuesioner Kepuasan Pelanggan Hotel Bintang. 2006

Hasil tanggapan responden pada Tabel 5.1 memberikan gambaran secara akumulasi penilaian responden terhadap dimensi kepuasan pada kontak personel yang dirasakan pelanggan pada industri hotel bintang di Daerah Istimewa Yogyakarta, nampak bahwa ketulusan karyawan merupakan indikator yang memberikan tingkat kepuasan tertinggi dibandingkan dengan indikator lainnya. Hal ini mengindikasikan bahwa karyawan hotel bintang di Daerah Istimewa Yogyakarta telah melayani tamu hotel dengan tulus yang hampir memenuhi harapan pelanggan.

Untuk melihat kategori penilaian pelanggan terhadap tingkat kepuasan berdasarkan perbandingan antara kinerja dengan harapan pada setiap indikator pada dimensi kontak person, nampak ketulusan karyawan merupakan indikator dengan tingkat kepuasan tertinggi yaitu $91,51 \%$, selanjutnya keramahan karyawan dengan tingkat kepuasan sebesar 88,54 \% dan kecepatan karyawan hotel dalam melayani tamu dengan kontribusi terkecil yaitu sebesar $87,18 \%$. Hasil skor penilaian secara keseluruhan pada dimensi kontak person, total penilaian pelanggan terhadap kepuasan pelanggan terhadap kontak person adalah sebesar $89,05 \%$. Kondisi ini mengindikasikan bahwa manajemen hotel bintang di Daerah Istimewa Yogyakarta mampu memberikan layanan kontak person yang hampir mendekati harapan pelanggan.

\subsection{Kepuasan Pelanggan Pada Fasilitas Fisik Pendukung Pada Hotel Bintang di Daerah Istimewa Yogyakarta.}

Fasilitas pendukung adalah fasilitas fisik pendukung proses penyampaian jasa hotel kepada pelanggan atau tamu yang menginap di hotel. Pernyataan responden terhadap fasilitas pendukung diukur dengan 4 indikator yang tercermin dalam item-item pertanyaan yang tersaji sebagai berikut :

\section{Kebersihan Kamar Pada Hotel Bintang di Daerah Istimewa Yogyakarta}

Kepuasan pelanggan pada kebersihan kamar hotel bintang di Daerah Istimewa Yogyakarta menurut tanggapan responden, dapat dilihat pada Tabel 5.2 berikut ini :

Data pada Tabel 5.2 mengindikasikan bahwa, hotel bintang tiga, empat dan lima di Daerah Istimewa Yogakarta belum dapat mememenuhi harapan akan kebersihan kamar. Hal ini ditunjukkan dari lebih besarnya nilai harapan responden akan kebersihan kamar hotel bintang tiga, empat dan lima dibandingkan dengan nilai kinerja yang dirasakan pelanggan, sehingga diperoleh indek kepuasan untuk kebersihan kamar hotel bintang sebesar $8,34 \%$. Hotel bintang tiga 
memberikan gab kepuasan terendah dibandingkan dengan bintang empat dan lima, hal ini dimungkinkan dengan harapan (expectation) pelanggan hotel bintang tiga yang lebih rendah dibansingkan dengan dua bintang lainnya.

Kebersihan kamar hotel merupakan salah satu faktor utama yang menjadi harapan dari tamu hotel. Sebagai produk lini hotel, kamar harus selalu dalam kondisi bersih dan rapi. Seperti yang diungkapkan oleh Bagyono $(2005 ; 89)$ bahwa dalam Dunia pariwisata, kebersihan (clealiness) merupakan salah satu aspek yang sangat berpengaruh terhadap kenyamanan wisatawan selama berkunjung dan menikmati liburannya di suatu tempat. Kebersihan kamar akan langsung mencerminkan kondisi pengelolaan manajemen hotel, hotel yang memiliki kamar yang bersih dan rapi akan membuat tamu atau pelanggan merasa nyaman untuk menginap di hotel. Berdasarkan hal tersebut maka, peran departemen Tata Graha (house keepping) sangat penting dalam menciptakan kebersihan khususnya kamar hotel.

Ketidakpuasan pelanggan terhadap kebersihan tidak hanya disebabkan oleh gab antara harapan dan kinerja kebersihan kamar yang dirasakannya, namun ketidak puasan pelanggan juga dapat disebabkan oleh gab antara persepsi manajemen dan spesifikasi kualitas (gap between management perceptions and service quality specification). Manajemen mungkin tidak membuat standar kualitas yang jelas, atau standar kualitas sudah jelas tetapi tidak realistik, atau standar kualitas sudah jelas dan realistik namun manjemen tidak berusaha untuk melaksanakan standar kualitas tersebut. Hal ini akan mengakibatkan karyawan tidak memahami tentang kebijakan perusahaan dan ketidak percayaan terhadap sikap manajemen, yang selanjutnya menurunkan prestasi kerja karyawan.

\section{Keindahan Interior kamar Pada Hotel Bintang di Daerah Istimewa Yogyakarta}

Kepuasan pelanggan pada keindahan interior kamar hotel bintang di Daerah Istimewa Yogyakarta menurut tanggapan responden dapat dilihat pada tabel 5.2 di bawah ini.

Berdasarkan data pada Tabel 5.2 mengindikasikan bahwa, hotel bintang tiga, empat dan lima di Daerah Istimewa Yogakarta belum dapat mememenuhi harapan akan keindahan interior kamar hotel. Hal ini ditunjukkan dari lebih besarnya nilai harapan responden akan keindahan interior kamar hotel pada hotel bintang tiga, empat dan lima dibandingkan dengan nilai, sehingga diperoleh indek kepuasan pelanggan untuk keindahan interior kamar hotel bintang 91,9\%. Angka tersebut juga mengindikasikan bahwa pelanggan yang menjadi responden hampir mencapai kepuasan pelanggan pada indikator keindahan interior kamar hotel.

Keindahan interior hotel yaitu menciptakan dekorasi yang menarik bagi tamu hotel yang menginap maupun yang hanya berkunjung di hotel. Khususnya pada hotel bintang di Daerah Istimewa Yogyakarta dalam penataan interior sebagian besar mengadaptasi dari kultur atau budaya daerah setempat, sehingga diharapkan atmosfer budaya Yogyakarta telah dirasakan oleh pelanggan pada saat masuk di hotel. Kondisi ini akan menciptakan kenyamanan bagi pelanggan untuk lebih menikmati budaya Yogyakarta di dalam hotel, sehingga tamu lebih merasa betah tinggal lama di hotel.

\section{Kebersihan Restoran dan Bar Pada Hotel Bintang di Daerah Istimewa Yogyakarta}

Kepuasan pelanggan pada kebersihan restoran dan bar hotel bintang di Daerah Istimewa Yogyakarta menurut tanggapan responden dapat dilihat pada Tabel 5.2.

Hasil peneilitian mengindikasikan bahwa, hotel bintang tiga, empat dan lima di Daerah Istimewa Yogakarta belum dapat mememenuhi harapan akan kebersihan restoran dan bar hotel. Hal ini ditunjukkan dari lebih besarnya nilai harapan responden akan kebersihan restoran dan bar hotel pada hotel bintang tiga, empat dan lima dibandingkan dengan nilai kinerja, sehingga diperoleh indek kepuasan pelanggan untuk kebersihan restoran dan bar hotel bintang tiga $88,82 \%$ Dari nilai tersebut mengindikasikan bahwa hotel bintang tiga lebih mampu memberikan kepuasan pelanggan berdasarkan kebersihan bar dan restoran hotel.

Bar maupun restoran merupakan salah satu produk lini dari hotel yang menjadi fasilitas pendukung bagi jasa hotel sangat berperan dalam menciptakan kepuasan pelanggan. Pentingnya kebersihan bar dan restoran dalam bisnis hospitality sangat menentukan Tanggapan 
responden terhadap kualitas layanan makanan yang diberikan. Seperti yang diungkapkan oleh Bagyono $(2005 ; 90)$ bahwa kebersihan restoran dan bar akan membawa dampak pada penciptaan suasana yang menyenangkan bagi tamu hotel yang makan dan minum di sana. Oleh karena itu, menciptakan suasana yang menyenangkan bagi pelanggan dapat dilakukan dengan menjaga kebersihan dan kerapian fasilitas layanannya.

\section{Ketersediaan Lahan Parkir Pada Hotel Bintang di Daerah Istimewa Yogyakarta}

Kepuasan pelanggan pada ketersediaan lahan parkir hotel bintang di Daerah Istimewa Yogyakarta menurut tanggapan responden dapat dilihat pada Tabel 5.2. Berdasarkan data pada Tabel 5.2 mengindikasikan bahwa, hotel bintang tiga, empat dan lima di Daerah Istimewa Yogakarta belum dapat mememenuhi harapan akan ketersediaan lahan parkir yang memadai. Hal ini ditunjukkan dari lebih besarnya nilai harapan responden akan kebersihan ketersediaan lahan parkir yang memadai pada hotel bintang tiga, empat dan lima dibandingkan dengan nilai kinerja, sehingga diperoleh indek kepuasan pelanggan ketersediaan lahan parkir yang memadai hotel bintang sebesar $86,3 \%$.

Lahan parkir merupakan salah satu fasilitas pendukung dalam layanan yang diberikan oleh hotel. Ketersediaan lahan parkir bagi pelanggan yang menginap sangat penting guna memberikan kenyaman dan rasa aman bagi tamu yang menginap membawa kendaraan. Fasillitas valet yang ditawarkan oleh pihak hotel juga merupakan salah satu layanan pada bagian parkir hotel selain tempat dan rasa aman tamu bila menginap di hotel. Wisatawan yang datang ke Yogyakarta dan menginap di hotel sebagian besar meruapakan wisatwan domestik yang membawa kendaraan sediri, sehingga keberadaan parkir yang memadai sangat dibutuhkan oleh pelanggan.

\section{Total Kepuasan Pelanggan Pada Fasilitas Fisik Pendukung Pada Hotel Bintang di Daerah Istimewa Yogyakarta}

Untuk mengetahui total skor tanggapan responden terhadap kepuasan responden pada fasilitas pendukung pada hotel bintang di Daerah
Istimewa Yogyakarta menurut tanggapan responden dapat di lihat pada Tabel 5.2. Hasil tanggapan responden memberikan gambaran secara akumulasi penilaian responden terhadap dimensi kepuasan pelanggan pada fasilitas pendukung yang dirasakan pelanggan pada industri hotel bintang di Daerah Istimewa Yogyakarta, nampak bahwa keindahan interior hotel merupakan indikator yang memberikan tingkat kepuasan tertinggi dibandingkan dengan indikator lainnya. Hal ini mengindikasikan bahwa hotel bintang di Daerah Istimewa Yogyakarta memberikan susana yang menyenangkan dengan menciptakan interior hotel yang hampir memenuhi harapan pelanggan

Tabel. 5.2. Total Kepuasan Pelanggan Pada Fasilitas Fisik Pendukung Menurut Tanggapan Responden

\begin{tabular}{|l|l|c|c|c|c|c|c|c|}
\hline \multirow{2}{*}{ Ukuran } & \multicolumn{6}{|c|}{ Distribusi Tanggapan Responden Pada Contact Personel } \\
\cline { 2 - 9 } & No. & 5 & 4 & 3 & 2 & 1 & $\begin{array}{c}\text { Total } \\
\text { Skor }\end{array}$ & $\begin{array}{c}\text { Tingkat } \\
\text { Kepuasan }\end{array}$ \\
\hline Kebersihan & Harapan & 185 & 113 & 2 & 0 & 0 & 1383 & 87,78 \\
Kamar & Kinerja & 56 & 202 & 42 & 0 & 0 & 1214 & \\
\hline Keindahan & Harapan & 136 & 164 & 0 & 0 & 0 & 1336 & 91,99 \\
Interior & Kinerja & 74 & 181 & 45 & 0 & 0 & 1229 & \\
\hline Kebersihan & Harapan & 198 & 120 & 4 & 0 & 0 & 1394 & 88,09 \\
restoran dan & Kinerja & 69 & 191 & 39 & 1 & 0 & 1228 & \\
bar & & & & & & & & \\
\hline Ketersediaan & Harapan & 180 & 120 & 0 & 0 & 0 & 1380 & 86,30 \\
lahan parkir & Kinerja & 50 & 191 & 59 & 0 & 0 & 1191 & \\
\hline Total & Harapan & 514 & 382 & 4 & 0 & 0 & 4110 & 88,75 \\
& Kinerja & 193 & 563 & 143 & 1 & 0 & 3648 & \\
\hline
\end{tabular}

Sumber : Hasil Pengolahan Kuesioner Kepuasan Pelanggan Hotel Bintang. 2006

Untuk melihat kategori penilaian pelanggan terhadap tingkat kepuasan berdasarkan perbandingan antara kinerja dengan harapan pada setiap indikator pada dimensi fasilitas pendukung, nampak keindahan interior merupakan indikator dengan tingkat kepuasan tertinggi yaitu $91,99 \%$, kebersihan restoran dan bar juga memberikan tingkat kepuasan yang tinggi yaitu sebesar 88,09, selanjutnya kebersihan kamar hotel dengan tingkat kepuasan sebesar $87,78 \%$ dan ketersediaan lahan parkir hotel dengan kontribusi terkecil yaitu sebesar $86,30 \%$. Hasil skor penilaian secara keseluruhan pada dimensi kontak person, total penilaian pelanggan terhadap kepuasan pelanggan terhadap fasilitas pendukung adalah sebesar $88,75 \%$. Kondisi ini mengindikasikan bahwa manajemen hotel bintang di Daerah Istimewa Yogyakarta mampu menyediakan fasilitas 
pendukung yang hampir mendekati harapan pelanggan.

\subsection{Kepuasan Pelanggan Pada Peralatan Pada Hotel Bintang di Daerah Istimewa Yogyakarta.}

Peralatan (equipment) adalah peralatan yang digunakan dalam menyampaikan pelayanan hotel kepada tamu atau pelanggan yang menginap diukur dengan 3 indikator yang tercermin dalam item-item pertanyaan yang tersaji sebagai berikut:

\section{Kesesuaian Televisi Dengan Standar Kamar Pada Hotel Bintang di Daerah Istimewa Yogyakarta}

Kepuasan pelanggan pada kesesuaian televisi dengan standar kamar hotel bintang di Daerah Istimewa Yogyakarta data pada Tabel 5.3 mengindikasikan bahwa, hotel bintang tiga, empat dan lima di Daerah Istimewa Yogakarta belum dapat mememenuhi harapan akan ketersediaan televisi yang sesuai standar kamar hotel bintang. Hal ini ditunjukkan dari lebih besarnya nilai harapan responden akan ketersediaan televisi yang sesuai standar kamar hotel bintang pada hotel bintang tiga, empat dan dibandingkan dengan nilai kinerja, sehingga diperoleh indek kepuasan pelanggan pada ketersediaan televisi yang sesuai standar kamar hotel $84,4 \%$. Dari ketiga hotel bintang tersebut mengindikasikan bahwa hotel bintang empat lebih mampu memberikan kepuasan pelanggan pada ketersediaan televisi yang sesuai standar kamar hotel bintang. Namun secara keseluruhan pelanggan sudah hampir puas terhadap ketersediaan televisi di kamar, walaupun belum mencapai kepuasan yang maksimum.

Salah satu peralatan dalam pelayanan jasa kamar hotel adalah pesawat televisi yang berfungsi sebagai peralatan sarana hiburan dalam kamar hotel. Penilaian kesesuaian pesawat televisi dengan standar kamar berkaitan dengan besarnya inci, umur televisi dan saluran yang disediakan oleh pihak hotel. Sebagai peralatan sarana hiburan di kamar, peranan televisi sangat penting untuk menciptakan kenyamanan pelanggan di dalam kamar hotel yang akan mempengaruhi kepuasan pelanggan terhadap equipment atau peralatan yang digunakan untuk melayani pelanggan. Perbedaan kelas kamar akan akan membawa dampak pada perbedaan harapan (expectation) pelanggan terhadap peralatan layanan yang akan dterimanya. Sehingga perusahaan harus jeli dalam membaca harapan (expectation) dari pelanggan.

\section{Kelangkapan Peralatan Kamar Mandi Pada Hotel Bintang di Daerah Istimewa Yogyakarta \\ Kepuasan pelanggan pada kelengkapan} fasilitas kamar mandi hotel bintang di Daerah Istimewa Yogyakarta menurut tanggapan responden dapat dilihat pada Tabel 5.3. Hasil penelitian ini mengindikasikan bahwa, hotel bintang tiga, empat dan lima di Daerah Istimewa Yogakarta belum dapat mememenuhi harapan akan kelengkapan peralatan kamar mandi hotel. Hal ini ditunjukkan dari lebih besarnya nilai harapan responden akan kelengkapan peralatan kamar mandi hotel pada hotel bintang dibandingkan dengan nilai kinerja yang masingmasing, sehingga diperoleh indek kepuasan pelanggan pada kelengkapan peralatan kamar mandi hotel bintang $87,5 \% . d$

Oka (2003;61) menjelaskan bahwa peralatan kamar mandi yang harus disediakan hotel bintang meliputi towel, soap, toothpaste, shampoo, pomade dan comb. Ketersediaan peralatan bagi tamu hotel merupakan bagian dari layanan hotel, sehingga ketidak beradaan bagian dari layanan tersebut akan mengurangi kualitas layanan sehingga nantinya berdampak pada kekecewaan dan ketidak puasan pelanggan. Oleh karena itu pihak hotel harus senantiasa menyiapkan perlengkapan mandi pelanggan dengan lengkap seperti yang telah di standarisasikan dalam layanan hotel bintang kepada pelanggan.

\section{Peralatan Makan di Restoran Pada Hotel Bintang di Daerah Istimewa Yogyakarta}

Kepuasan pelanggan pada peralatan makan dan minuman di restoran hotel bintang di Daerah Istimewa Yogyakarta menurut responden dapat dilihat pada Tabel 5.3.

Berdasarkan data pada tabel di atas mengindikasikan bahwa, hotel bintang tiga, empat dan lima di Daerah Istimewa Yogakarta belum dapat mememenuhi harapan akan kelengkapan peralatan kamar mandi hotel. Hal ini ditunjukkan dari lebih besarnya nilai harapan responden peralatan makan dan minuman yang memadai di restoran hotel pada hotel bintang tiga, empat dan 
lima dibandingkan dengan nilai kinerja, sehingga diperoleh indek kepuasan pelanggan pada peralatan makan dan minum di restoran hotel bintang $84,5 \%$.

Hasil tersebut mengindikasikan bahwa, peralatan makan dan minum pada Hotel bintang tiga, empat dan lima di Daerah Istimewa Yogyakarta masih belum memadai seperti yang diharapkan oleh pelanggan. Selain kualitas makanan dan minuman di restoran hotel, peralatan makanan pada hotel juga menjadi perhatian pelanggan guna memuaskan kebutuhannya. Pada restoran hotel bintang peralatan yang digunakan memiliki kualitas dan keanekaragaman yang lebih dibandingkan restoran biasa. Hal ini diciptakan pihak hotel bintang untuk lebih memberi nilai yang lebih bagi pelanggan dengan mencipakan kesan mewah dalam pelayanan, yang akhirnya diharapkan dapat memberikan kepuasan bagi pelanggan. Pengunaan peralatan makan dan minuman yang kurang memadai atau sesuai dengan standar restoran hotel bintang, akan menurukan kualitas layanan restoran hotel yang nanti akan berdampak pada kepuasan pelanggan. Oleh sebab itu penting kiranya bagi pihak hotel untuk melakukan pembaharuan terhadap peralatan makan dan minuman yang sudah tidak memadai lagi bila disajikan di restoran hotel bintang.

\section{Total Kepuasan Pelanggan Pada Peralatan Pada Hotel Bintang di Daerah Istimewa Yogyakarta}

Untuk mengetahui total kepuasan pelanggan pada peralatan yang digunakan untuk melayanai pelanggan hotel bintang di Daerah Istimewa Yogyakarta menurut tanggapan responden dapat di lihat pada Tabel 5.3 berikut :
Tabel. 5.3. Total Kepuasan Pelanggan Pada Peralatan Menurut Tanggapan Responden

\begin{tabular}{|c|c|c|c|c|c|c|c|c|}
\hline \multirow[t]{2}{*}{ Ukuran } & \multicolumn{8}{|c|}{ Distribusi Tanggapan Responden Pada Contact Personel } \\
\hline & No. & 5 & 4 & 3 & 2 & 1 & $\begin{array}{l}\text { Total } \\
\text { Skor }\end{array}$ & $\begin{array}{l}\text { Tingkat } \\
\text { Kepuasan }\end{array}$ \\
\hline \begin{tabular}{|l} 
Kesesuaian \\
televisi \\
dengan \\
standar kamar
\end{tabular} & $\begin{array}{l}\text { Harapan } \\
\text { Kinerja }\end{array}$ & $\begin{array}{c}155 \\
36\end{array}$ & $\begin{array}{l}134 \\
162\end{array}$ & $\begin{array}{c}11 \\
102\end{array}$ & $\begin{array}{l}0 \\
0\end{array}$ & $\begin{array}{l}0 \\
0\end{array}$ & $\begin{array}{l}1344 \\
1134\end{array}$ & 84,37 \\
\hline $\begin{array}{l}\text { Kelengkapan } \\
\text { peralatan } \\
\text { kamar mandi }\end{array}$ & $\begin{array}{l}\text { Harapan } \\
\text { Kinerja }\end{array}$ & $\begin{array}{c}199 \\
74\end{array}$ & $\begin{array}{l}101 \\
176\end{array}$ & $\begin{array}{c}0 \\
50\end{array}$ & $\begin{array}{l}0 \\
0\end{array}$ & $\begin{array}{l}0 \\
0\end{array}$ & $\begin{array}{l}1399 \\
1224\end{array}$ & 87,49 \\
\hline $\begin{array}{l}\text { Kelengkaoan } \\
\text { peralatan } \\
\text { makan } \\
\text { direstoran } \\
\end{array}$ & $\begin{array}{l}\text { Harapan } \\
\text { Kinerja }\end{array}$ & $\begin{array}{c}175 \\
45\end{array}$ & $\begin{array}{l}124 \\
172\end{array}$ & $\begin{array}{c}1 \\
82\end{array}$ & $\begin{array}{l}0 \\
1\end{array}$ & $\begin{array}{l}0 \\
0\end{array}$ & $\begin{array}{l}1374 \\
1161\end{array}$ & 84,49 \\
\hline Total & $\begin{array}{l}\text { Harapan } \\
\text { Kinerja }\end{array}$ & $\begin{array}{l}529 \\
155\end{array}$ & $\begin{array}{l}359 \\
519\end{array}$ & $\begin{array}{c}12 \\
234 \\
\end{array}$ & $\begin{array}{l}0 \\
1\end{array}$ & $\begin{array}{l}0 \\
0\end{array}$ & $\begin{array}{l}4117 \\
3519 \\
\end{array}$ & 85,47 \\
\hline
\end{tabular}

Sumber : Hasil Pengolahan Kuesioner Kepuasan Pelanggan Hotel Bintang. 2006

Hasil tanggapan responden pada Tabel 5.3 memberikan gambaran secara akumulasi penilaian responden terhadap dimensi kepuasan pelanggan pada peralatan yang digunakan dalam penyampaian jasa yang dirasakan pelanggan pada industri hotel bintang di Daerah Istimewa Yogyakarta, nampak bahwa kelengkapan kamar mandi hotel merupakan indikator yang memberikan tingkat kepuasan tertinggi dibandingkan dengan indikator lainnya. Hal ini mengindikasikan bahwa hotel bintang di Daerah Istimewa Yogyakarta mampu menyediakan kelengkapan kamar mandi yang hampir memenuhi harapan pelanggan.

Untuk melihat kategori penilaian pelanggan terhadap tingkat kepuasan berdasarkan perbandingan antara kinerja dengan harapan pada setiap indikator pada dimensi peralatan, nampak kelengkapan kamar mandi merupakan indikator dengan tingkat kepuasan tertinggi yaitu $87,49 \%$, selanjutnya kebersihan rumah makan dengan tingkat kepuasan sebesar $84,49 \%$ dan kesesuaian televisi dengan standar kamar memberikan kontribusi terkecil yaitu sebesar 86,30 $\%$. Hasil skor penilaian secara keseluruhan pada dimensi peralatan, total penilaian pelanggan terhadap kepuasan pelanggan terhadap peralatan adalah sebesar $84,47 \%$. Kondisi ini mengindikasikan bahwa manajemen hotel bintang di Daerah Istimewa Yogyakarta mampu menyediakan peralatan yang hampir mendekati harapan pelanggan. 
5.4 Uji Hipotesis : Hotel bintang tiga, empat dan lima di Daerah Istimewa Yogyakarta memberikan kepuasan bagi pelangan

Dengan menggunakan analisis uji rata-rata terhadap variabel kepuasan pelanggan bintang tiga empat dan lima di Daerah istimewa Yogyakarta maka diperolah hasil seperti pada Tabel 5.4 Berdasarkan tabel tersebut menginidikasikan bahwa bahwa hotel bintang tiga empat dan lima di Daerah Istimewa Yoyakarta belum memberikan kepuasan pelanggan yang maksimal. Hal ini ditunjukkan lebih tingginya harapan pelanggan terhadap kontak personal, fasilitas fisik pendukung dan peralatan dibandingkan kinerja yang dirasakan oleh pelanggan.

Tabel 5.4. Hasil Uji Deskriptif Variabel Nilai Pelannggan

\begin{tabular}{|l|l|c|c|l|}
\hline $\begin{array}{l}\text { No } \\
.\end{array}$ & Hipotesis & $\begin{array}{c}\text { Rata-Rata } \\
\text { Hasil }\end{array}$ & $\begin{array}{l}\text { Rata- } \\
\text { Rata }\end{array}$ & Keputusan \\
\hline & $\begin{array}{l}\text { Hotel bintang } \\
\text { tiga, empat dan } \\
\text { lima di Daerah }\end{array}$ & 0,88 & 1 & $\begin{array}{l}\text { Ho diterima, Hotel } \\
\text { bintang tiga, } \\
\text { empat dan lima di } \\
\text { Daerah Istimewa } \\
\text { Istimewa }\end{array}$ \\
$\begin{array}{l}\text { Yogyakarta } \\
\text { memberikan } \\
\text { kepuasan bagi } \\
\text { pelanggan }\end{array}$ & & & $\begin{array}{l}\text { Yogyarta belum } \\
\text { memberikan } \\
\text { kepuasan bagi } \\
\text { pelanggan }\end{array}$ \\
\hline
\end{tabular}

Kontak person merupakan sub variabel memberikan skor kepuasan tertinggi dibandingkan dua variabel manifest kepuasan pelanggan lainnya, dan Fasilitas fisik pendukung layanan hotel memberikan kepuasan kedua terbesar setelah kontak personal dalam membentuk kepuasan pelanggan. Hasil penelitian ini juga mengindikasikan bahwa menguatnya kepuasan pelanggan merupakan implikasi dari baiknya peralatan yang dimiliki hotel dalam melakukan delivery service process kepada pelanggan.

\section{DAFTAR PUSTAKA}

A.B Sutanto, 2004. Value Marketing: Paradigma Baru Pemasaran. Nizn Media Utama Bandung

Allen, Derek R, 2004. Customer Satisfaction Research Management : A Comprehensive Guide to Integrating Customer Loyalty and Satisfaction Metrics in the Management of Complex Organizations. American Society for
Quality, Quality Press, Milwaukee 53203

Catro C.B, M.E Armario and Ruiz D.M, 2004. The Influence of Employee Organizational Citizenship Behavior on Customer Loyalty. International Service od Journal Industry Management, Vol 15 No 12004 pp. 27-53

Giese, Joan L. and Joseph A. Cote, 2002. Defining Consumer Satisfaction, Academy of Marketing Science Review, 2000 (1), 1-24.

Kotler, Philip. 2003. Manajemen Pemasaran. Jakarta : PT. Prenhallindo

Nguyen, Nha and Gaston Leblanc,. 2002. Contact Personel, Physical Enviromet and the Perceived Corporate Image of Intangible Service by New Client. International Journal of Service Industry Management. Volume 13. No 13. pp 242-262

Pritchard, Michael and Rhian Silvestro, 2005. Applying The Service Profit Chain to Analyse Retail Performance: The case of the Managerial Strait-Jaket. International od Service Journal Industry Management, Vol. 16 No 4. pp. 337-356

Sekaran, Umar, 2006. Research Methods For Business "Metodologi Penelitian untuk Bisnis. Edisi Pertama. Salemba Empat.

Shankar, Venkatesh, Amy K. Smith, and Arvind Rangaswamy.2003,Customer Sastifaction and Loyalty in Online and Offline Environments, International Journal of Research in Marketing, 20 (2), 153-175.

Sweeney, Jillian C. and Geoffrey N. Soutar, 2001. Consumer Perceived Value: The Development of a Multiple Item Scale, Journal of Retailing, 77 (2), 203-20.

Ueltschy, Linda C, Michel Laroche, Robert D. Tamilia, and Peter Yannopoulos, 2004. Cross-cultural Invariance of Measures of Satisfaction and Service Quality, Journal of Business Research, 57 (8), 901-912. 
Walker, Boyd, and Larreche Mullins, 2003. Marketing Strategic: A DecisionFocused Approach, Fourth Edition, International Edition, Mc-Graw Hill, USA.

Wang, Yonngui, Hing Po Lo, Renyong Chi, and Yongyeng Yang, 2004., An Integrated Framework for Customer Value and Customer-Relationship-Management

Performance: A Customer-Based Perspective From China, Managing Service Quality, 14 (2/3), 169-182.

Zeithaml Valerie A, M.J. Bitner, 2003 . Service Marketing. First edition, USA : Mc Graw-Hil 